\title{
IL7 signaling confers polyfunctionality to antitumor CD4+ T cells
}

\author{
Gang Zhou*, Zhi-Chun Ding \\ From Society for Immunotherapy of Cancer 29th Annual Meeting \\ National Harbor, MD, USA. 6-9 November 2014
}

Mounting evidence indicates that polyfunctional $\mathrm{T}$ cells, effector $\mathrm{T}$ cells capable of simultaneously producing multiple pro-inflammatory cytokines, are more efficacious in controlling infection and cancer. Our previous study reported that adoptive transfer of tumor-specific CD4+ T cells following chemotherapy gave rise to polyfunctional $\mathrm{CD} 4+$ effector cells, characterized by concomitant expression of CD40L, IFN $\gamma$, TNF $\alpha$, IL2 and granzyme B. One unique feature of these highly activated polyfunctional CD4+ effector cells was the high level expression of IL7 receptor, suggesting that IL7 plays a critical role in the generation and maintenance of these cells. In this project, we studied how IL7 signaling confers polyfunctionality to CD4+ T cells. We found that only IL7, but not other IL2 family cytokines can promote the acquisition of polyfunctionality in naïve $\mathrm{CD} 4+\mathrm{T}$ cells upon antigenic stimulation in vitro. IL7 signaling resulted in increased histone acetylation in the promoters of effector molecules including IFNgamma and IL2. Mechanistically, PI3K activation was required for polyfunctionality. Administration of rIL7 following chemotherapy and CD4+ T cell adoptive therapy led to enhanced and sustained presence of polyfunctional CD4+ effector cells which mediated durable antitumor effects in mice with advanced B cell lymphomas. Our results provide novel insights into the mechanisms by which IL7 drives the generation of polyfunctional CD4+ effector cells.

Submit your next manuscript to BioMed Central and take full advantage of:

- Convenient online submission

- Thorough peer review

- No space constraints or color figure charges

- Immediate publication on acceptance

- Inclusion in PubMed, CAS, Scopus and Google Scholar

- Research which is freely available for redistribution
() Biomed Central

Georgia Regents University, Augusta, GA, United States

(c) 2014 Zhou and Ding; licensee BioMed Central Ltd. This is an Open Access article distributed under the terms of the Creative Commons Attribution License (http://creativecommons.org/licenses/by/4.0), which permits unrestricted use, distribution, and reproduction in any medium, provided the original work is properly cited. The Creative Commons Public Domain Dedication waiver (http://creativecommons.org/publicdomain/zero/1.0/) applies to the data made available in this article, unless otherwise stated. 